\title{
OPTIMIZATION OF PARTICLE BOMBARDMENT CONDITIONS FOR RICE (Oryza sativa L.) TRANSFORMATION
}

\author{
Zahid Mukhtar ${ }^{1, *}$ and Shahida Hasnain ${ }^{2}$ \\ ${ }^{1}$ National Institute for Biotechnology and Genetic Engineering (NIBGE), P.O. Box 577, Jhang Road, Faisalabad, \\ Pakistan; ${ }^{2}$ Department of Microbiology and Molecular Genetics, University of the Punjab, Lahore, Pakistan. \\ "Corresponding author's: e-mail: zahidmukhtar@yahoo.com
}

\begin{abstract}
Many factors which affect bombardment efficiency were studied and optimized to develop a simple and reproducible system for transformation of rice through particle-bombardment. Conditions were optimized by varying particle size, helium pressure, target distance and DNA/particle loads. Effect of pre- and post-bombardment osmotic treatment and effective concentration of hygromycin B for selection of transformed cells were also investigated. Both types of explants gave an equally good response in transient GUS expression, however, mature embryos were found to be more suitable giving higher selection efficiency. Gold particles of $1 \mu \mathrm{m}$ size, helium pressure of 1,100 psi, target distance of $9 \mathrm{~cm}$ and a DNA to particle ratio of 3:1 produced the highest transient GUS expression in embryos. Osmotic treatment resulted in 2.7 to 2.9 fold increase in transient $G U S$ expression. Hygromycin B at $50 \mathrm{mg} \mathrm{L}^{-1}$ was found to be optimum for effective selection of transformed cells. Transgenic plants were recovered at an average transformation efficiency of $1.5 \%$. Analysis of putative transgenic plants revealed that $96 \%$ of the recovered plants were positive for both GUS and hpt genes. All the established plants were phenotypically normal and fertile.
\end{abstract}

Keywords: Rice, basmati, GUS, particle bombardment, transgenic plants

\section{INTRODUCTION}

Direct DNA transfer methods for genetic transformation of plants depend entirely on physical or chemical principles to deliver DNA into the plant cells (Altpeter et al., 2005). Many different direct DNA transfer methods have been described by various workers including particle bombardment (Klein et al., 1987; Christou et al., 1992; Finer et al., 1992), polyethyleneglycol mediated transformation of protoplasts (Negrutiu et al., 1987; Datta et al., 1990), micro-injection (Crossway et al., 1986), electroporation (Shillito et al., 1985; Fromm et al., 1986) and transformation using silicon-carbide whiskers (Frame et al., 1994; Asad et al., 2008). The delivery of transgenes into embryonic tissues by particle mediated transformation continues to be the principal direct DNA transfer technique in plant biotechnology (James, 2003). Particle bombardment technology has proved to be an effective and versatile method of gene delivery over the past few decades. It has demonstrated several advantages, over other gene transfer techniques, like i) diverse cell types can be used as targets, ii) minimal expression cassettes can be used without the requirement of a vector backbone, iii) multigene transformation is achievable, iv) high molecular weight DNA delivery into plant cells is possible, and v) it is one of the most convenient method for organelle transformation (Altpeter $e t$ al., 2005).

The present study deals with the development of reproducible procedures for particle-bombardment mediated transformation of rice by optimization of different biological and physical parameters which can have a dramatic effect on gene delivery to the targeted cells.

\section{MATERIALS AND METHODS}

Plasmids used for transformation: Two plasmids pGH-I and pGH-II (Fig. 1) having cloned GUS and hpt genes were used in this study. Both plasmids contained hpt gene having CaMV35S promoter, tml terminator and GUS gene under the control of rice actin-1 promoter and nos terminator.
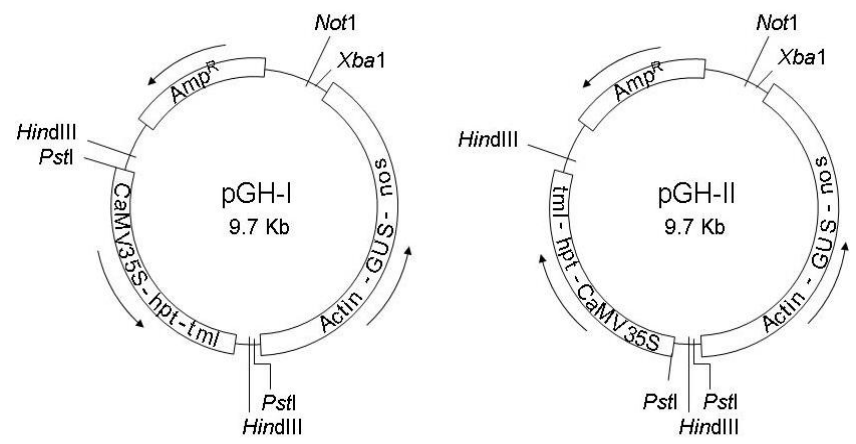

CaMV35S $-h p t-\mathrm{tml}=1.7 \mathrm{~Kb}$

Actin - GUS - nos $=4.36 \mathrm{~Kb}$

$\rightarrow$ Direction of transcription

Figure 1.Physical map of the co-integrate vectors pGH-1 and pGH-II. 
These plasmids were transformed into electro-competent cells of $E$. coli strain DH5 $\alpha$ through electroporation. The transformed cells were spread onto LB agar plates containing ampicillin $\left(50 \mu \mathrm{g} \mathrm{ml}^{-1}\right)$. Plasmid DNA was isolated from the transformed colonies following alkaline lysis method.

Preparation of plant material for bombardment: Embryogenic calli (28 days old) and mature embryos were used as the target material for bombardment. Embryogenic calli were induced on optimized callus induction medium (Table 1). About 30-40 calli of 3-4 mm size were arranged on bombardment medium. For mature embryos, seeds were soaked overnight in sterile water and embryos were excised under a stereo-microscope. Approximately 50-60 embryos were arranged on the bombardment medium (Fig. 2a).

Table 1. Composition of different media used for callus induction, bombardment, selection and plant regeneration from bombarded explants.

\begin{tabular}{|c|c|c|}
\hline Medium & Purpose & Composition \\
\hline CI & $\begin{array}{l}\text { Callus } \\
\text { induction }\end{array}$ & $\begin{array}{l}\text { MS salts and vitamins, } 2,4-\mathrm{D} 2 \mathrm{mgL}^{-1} \text {, } \\
\text { sucrose } 3.0 \% \text {, agar } 1.0 \% \text {, pH } 5.7-5.8\end{array}$ \\
\hline BM & $\begin{array}{l}\text { Bombardmen } \\
\mathrm{t}\end{array}$ & $\begin{array}{l}\text { MS salts and vitamins, with } 2 \mathrm{mg} \mathrm{L}^{-1} \\
2,4-\mathrm{D}, 3 \% \text { sucrose and } 0.25 \mathrm{M} \\
\text { mannitol, phytagel } 0.25 \%, \mathrm{pH} 5.7-5.8\end{array}$ \\
\hline SM & Selection & $\begin{array}{l}\text { CI medium having hygromycin-B } 50 \\
\mathrm{mg} \mathrm{L}^{-1}\end{array}$ \\
\hline PR-1 & $\begin{array}{l}\text { Pre- } \\
\text { regeneration }\end{array}$ & $\begin{array}{l}\text { MS salts and vitamins, kinetin } 3 \mathrm{mg} \mathrm{L}^{-1} \text {, } \\
\text { NAA } 1 \mathrm{mg} \mathrm{L}^{-1} \text {, maltose } 30 \mathrm{~g} \mathrm{~L}^{-1} \text {, } \\
\text { sorbitol } 30 \mathrm{~g} \mathrm{~L}^{-1} \text {, abscisic acid } 10 \mathrm{mg} \\
\mathrm{L}^{-1} \text {, phytagel } 0.25 \% \text {, pH } 5.8\end{array}$ \\
\hline PR-2 & Regeneration & Same as PR-1 except abscisic acid \\
\hline $\mathrm{RP}$ & $\begin{array}{l}\text { Root } \\
\text { Proliferation }\end{array}$ & $\begin{array}{l}1 / 2 \text { strength MS salts and vitamins, } \\
\text { sucrose } 2.0 \% \text {, phytagel } 0.2 \%, \mathrm{pH} \\
5.7-5.8\end{array}$ \\
\hline
\end{tabular}

Preparation of DNA coated bullets and bombardment: Particle bombardment was carried out using Particle Delivery System (PDS-1000/He; BioRad, USA). Preparation of microprojectiles, precipitation of plasmid DNA on the microprojectiles and bombardment procedure was followed as described by the manufacturer. Initially, both types of target tissues were bombarded with $5 \mu \mathrm{g}$ plasmid DNA using $3 \mathrm{mg}$ gold particles of $1.0 \mu \mathrm{m}$ size, with rupture discs of $1,100 \mathrm{psi}$ and keeping the target distance of $9 \mathrm{~cm}$.

Histochemical GUS assay: GUS assay was performed following Jefferson et al. (1987). Methanol was added to the buffer solution at a final concentration of $20 \%$ to suppress endogenous $\beta$-glucuronidase activity following Kosugi et al. (1990). Transient GUS expression was observed 24-48 h after bombardment of explants by overnight incubation in the GUS staining solution (88.9 mg X-Gluc, $10.0 \quad \mathrm{mg}$ Chloramphenicol, $1.0 \mathrm{ml} \mathrm{NaH} \mathrm{PO}_{4}$ (0.2 M stock), $1.0 \mathrm{ml}$ Triton X-100, $20.0 \%$ Methanol, $\mathrm{pH} 7.0-8.0)$ at $37^{\circ} \mathrm{C}$. Numbers of blue loci were counted under the stereomicroscope.
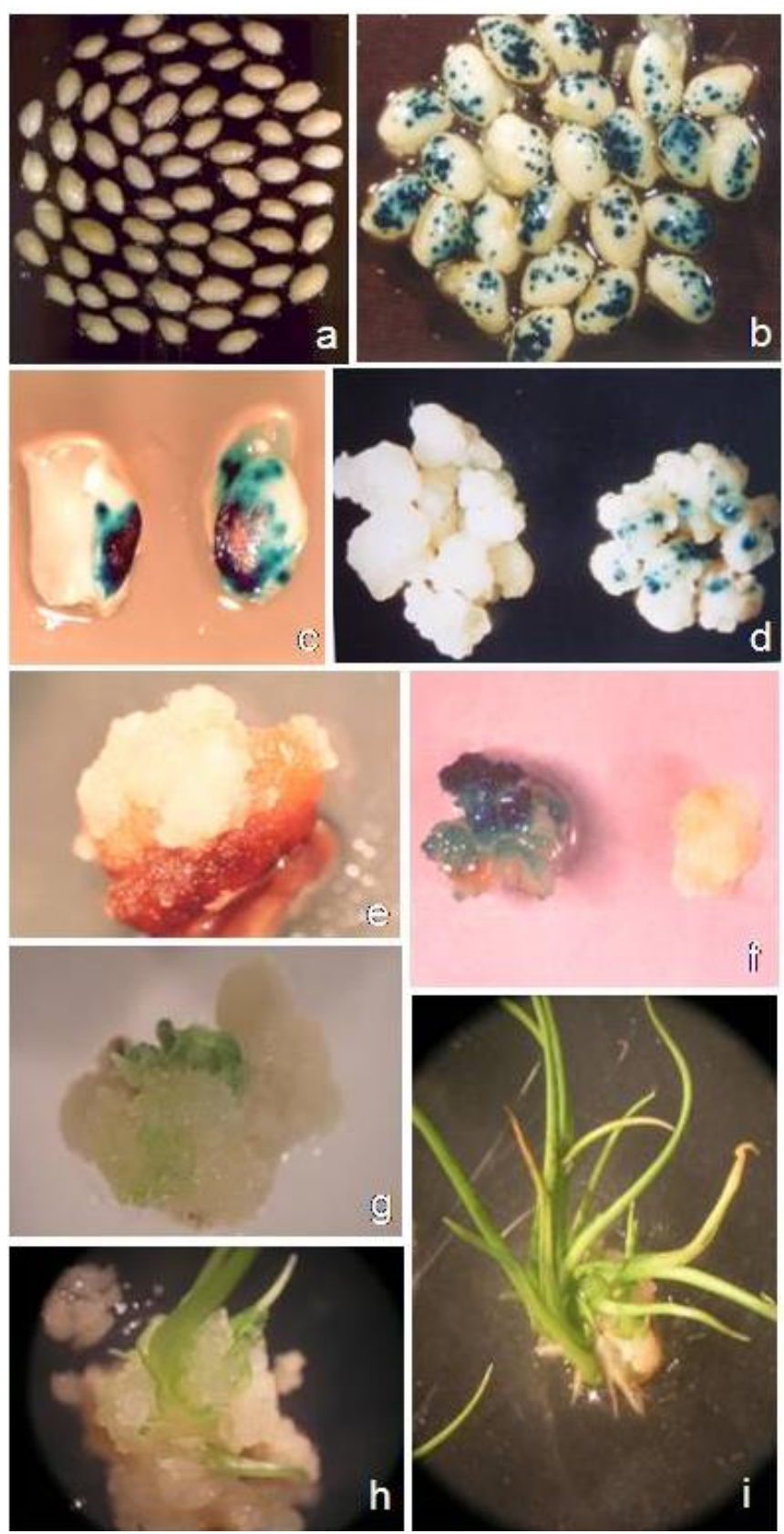

Figure 2. Particle-bombardment of Basmati-370 mature embryos and embryogenic calli with pGHI/pGH-II for transient $\boldsymbol{G} \boldsymbol{U} \boldsymbol{S}$ expression studies; a) arrangement of mature rice embryos of B-370 on bombardment medium; b-c) mature embryos bombarded under different bombardment conditions, stained with GUS substrate $24 \mathrm{~h}$ after the bombardment showing transient GUS expression; d) bombarded embryogenic calli showing GUS expression; e) proliferation of hyg ${ }^{\mathrm{R}}$ callus from scutellar surface of bombarded embryo; $f$ ) actively growing hyg ${ }^{\mathrm{R}}$ callus (left) and a non-transformed control (right) stained with GUS substrate; g-i) plant regeneration from hyg $^{\mathrm{R}}$ resistant calli. 
Optimization of different parameters affecting bombardment efficiency: Following parameters were optimized for high efficiency DNA delivery to the target tissues including particle size, helium pressure, target distance, number of shots and effect of osmotic treatment. Gold particles of 1.0 and $1.6 \mu \mathrm{m}$ size were used for bombardment. Ruptures discs of 1,100 and 1,550 psi were used. The embryos were bombarded at distances of 3,6,9 and $12 \mathrm{~cm}$. DNA loads from 3 to $15 \mu \mathrm{g}$ were used to coat $3-5 \mathrm{mg}$ gold particles in three different particle:DNA ratios i.e., 1:1, 1:2 and 1:3, respectively. Each DNA-gold prep was used for six bombardments. Effect of pre- and post-bombardment osmotic treatment having 3\% sucrose (control) and additional 0.25 and $0.4 \mathrm{M}$ mannitol in the bombardment medium (Table 1) was studied to define a suitable medium. Other parameters like vacuum, macro-carrier flight distance and the gap between rupture disc and macro-carrier were kept constant at 27 inches of $\mathrm{Hg}, 8 \mathrm{~mm}$ and $6.5 \mathrm{~mm}$, respectively.

Selection, plant regeneration and establishment of regenerated plants in hydroponics/soil: For determining optimum concentration of Hygromycin B (hyg-B) for selection, embryogenic calli developed from mature seeds were placed on callus induction (CI) medium having different concentrations $\left(0,25,50\right.$ and $\left.100 \mathrm{mg} \mathrm{L}^{-1}\right)$ of hyg-B. Data regarding the effectiveness of hyg-B for selection was recorded after 30 days.

Hygromycin resistant $\left(\mathrm{hyg}^{\mathrm{R}}\right)$ calli were transferred to optimized pre-regeneration (PR-1) medium (Table 1) containing $50 \mathrm{mg} \mathrm{L}{ }^{-1}$ hyg-B. About $10-12$ hyg $^{\mathrm{R}}$ calli were transferred to PR-1 medium in petri plates. After 10-12 days, the calli were transferred to plant regeneration (PR-2) medium (Table 1). After another two weeks, calli producing plantlets were transferred to fresh PR-2 medium. The regenerated plantlets were transferred to root proliferation (RP) medium (Table 1). Putative transgenic plants were acclimatized and established first in sand and then transferred to soil in earthen pots and kept in glass-house for further growth.

Molecular analysis of putative transgenic plants: DNA was isolated using CTAB method following Iqbal et al. (1997). PCR reaction was performed in $25 \mu$ l of reaction mixture (2.5 $\mu 110$ X PCR buffer, $3.0 \mu \mathrm{l}$ dNTPs $(1 \mathrm{mM}), 20-40 \mathrm{ng}$ of each primer, $0.2 \mu \mathrm{l}$ Taq polymerase $(5 \mathrm{u} / \mu \mathrm{l}), 3.5 \mu \mathrm{l} \mathrm{MgCl}_{2}(15 \mathrm{mM})$ containing 50-100 ng DNA from the putative transgenic and the non-transformed plants, RG100 (Ghareyazie et al., 1997) and either GUS or hpt primers. The reaction mixture was subjected to 1 cycle of $94^{\circ} \mathrm{C}$ for $5 \mathrm{~min}$ followed by 35 cycles of $94^{\circ} \mathrm{C}$ for $1 \mathrm{~min}, 60^{\circ} \mathrm{C}$ for $1 \mathrm{~min}, 72^{\circ} \mathrm{C}$ for $3 \mathrm{~min}$ and $1 \mathrm{cycle}$ of $5 \mathrm{~min}$ at $72^{\circ} \mathrm{C}$ to complete the reaction. Following controls were included in PCR analysis: i) water control, ii) negative control i.e. DNA from a non-transgenic plant, iii) plasmid DNA control, and iv) internal control. After amplification, 10 $\mu \mathrm{l}$ of each PCR product was electrophoresed through $1.8 \%$ agarose gel, containing $0.5 \mu \mathrm{g} / \mu \mathrm{l}$ ethidium bromide, at $100 \mathrm{~V}$ for 3-4 h. The size of PCR products was visualized under UV light.

\section{RESULTS}

Optimization of bombardment parameters affecting bombardment efficiency:

Effect of type, physiological and developmental stage of the target tissue: Calli as well as mature embryos both showed good transient $G U S$ expression and large number of blue loci were observed after bombardment as shown in Figure 1. Primary calli were easy to get and maintain, however their selection efficiency was not good as some sectors of bombarded calli kept on growing even at the highest concentration $(100 \mathrm{mg} / \mathrm{L})$ of hyg-B used in the selection medium. The transformed calli after two weeks of selection could be differentiated from non-transformed calli as white to pale yellow in colour and relatively fast-growing cells. However, when these calli were sub-cultured to fresh medium some of the sectors turned necrotic indicating a need for further selection. The calli which lived on selection medium for a longer time had reduced regeneration ability. When mature embryos were bombarded with plasmid $\mathrm{pGH}-\mathrm{I} / \mathrm{pGH}-$ II, callus mostly originated only from the transformed sectors of the scutellum surface (Fig. 2e). The originating callus was easily and effectively selected during two selection passages. Moreover, its origin and fast growth gave a clear and early indication of transgenic nature. Better selection efficiency of mature embryos in the initial experiments prompted us to use this explant for detailed studies. For most of the subsequent optimization work, mature embryos were used.

Effect of particle size, helium pressure and target distance on bombardment efficiency: Figure 3 shows the results of varying particle size, helium pressure and target distance on transient GUS expression in rice embryos. The values shown in Figure 3 are means of three replicates. In this experiment, DNA and particle load were kept constant at $5 \mu \mathrm{g}$ and $0.5 \mathrm{mg}$ per bombardment following manufacturer's instructions. Vacuum, macro-carrier flight distance and the gap between the rupture disc and macro-carrier were also kept constant at 27 inches of $\mathrm{Hg}, 8 \mathrm{~mm}$ and $4 \mathrm{~mm}$, respectively. Highest number of blue loci $(350.7 \pm 43.6)$ was observed when the embryos were bombarded at $6 \mathrm{~cm}$ with $1.0 \mu \mathrm{m}$ gold particles and a pressure of 1,100 psi. The lowest transient GUS expression $(7.0 \pm 2.6)$ was recorded with $1.6 \mu \mathrm{m}$ gold particles at $1,550 \mathrm{psi}$ pressure and $3 \mathrm{~cm}$ target distance. Target distance of $3 \mathrm{~cm}$ resulted in poor transient GUS expression. At this distance, higher helium pressure $(1,550 \mathrm{psi})$ or bigger particles $(1.6 \mu \mathrm{m})$ further reduced the number of blue loci. This decreased transient GUS expression may be a result of tissue damage due to a higher number of particles hitting per unit area. At $6 \mathrm{~cm}$, the highest number of blue loci was observed with $1.0 \mu \mathrm{m}$ particles at a pressure of 1,100 psi. When the pressure or particle size was increased, the transient 
GUS expression decreased. Although highest number of blue loci was obtained at bombardment distance of $6 \mathrm{~cm}$ with 1.0 $\mu \mathrm{m}$ particles and 1,100 psi helium pressure; however, more consistent results were obtained when the embryos were bombarded at $9 \mathrm{~cm}$ at both pressures and particle sizes. At 9 $\mathrm{cm}$ target distance, highest number of blue loci was recorded at $1,550 \mathrm{psi}$ helium pressure with $1.0 \mu \mathrm{m}$ gold particles followed by 1,100 psi pressure and $1.0 \mu \mathrm{m}$ gold. Bombardment distance of $9 \mathrm{~cm}$ resulted in more uniform dispersion of particles over the target area and reduced the tissue damage compared to higher pressure (1,550 psi) or bigger particles $(1.6 \mu \mathrm{m})$. Transient $G U S$ expression was significantly reduced as the target distance was increased to $12 \mathrm{~cm}$. From these results it can be concluded that particle size of $1.0 \mu \mathrm{m}$ is more suitable than $1.6 \mu \mathrm{m}$ for mature embryos while a helium pressure of $1,100 \mathrm{psi}$ at $6 \mathrm{~cm}$ or either 1,100 or 1,550 at a target distance of $9 \mathrm{~cm}$ can be used for high efficiency DNA delivery to these target tissues.

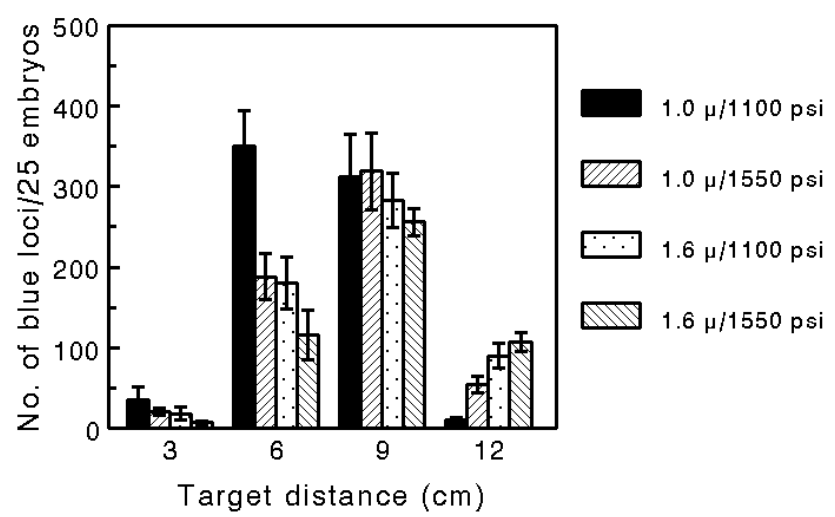

Figure 3. Effect of particle size, helium pressure and target distance on transient GUS expression in mature embryos of B-370.

Effect of particle and DNA loads: Different DNA to particle ratios and loads (combinations A-G; Fig. 4) were used to determine suitable combination for high efficiency DNA delivery to target tissues. Gold particles of $1 \mu \mathrm{m}$ size, helium pressure of $1100 \mathrm{psi}$ and a target distance of $9 \mathrm{~cm}$ was used for these experiments. Vacuum, macro-carrier flight distance and the gap between the rupture disc and macro-carrier were kept constant as described previously. Maximum number of blue loci $(405.3 \pm 32.1)$ were observed in combination $\mathrm{C}$ where $9 \mu \mathrm{g}$ DNA was used with $3 \mathrm{mg}$ gold while lowest number of blue loci $(101.0 \pm 19.0)$ were recorded in combination A where $3 \mu \mathrm{g}$ DNA was used with $3 \mathrm{mg}$ gold particles. At $3 \mathrm{mg}$ gold, decreasing the DNA load from $9 \mu \mathrm{g}$ (combination $\mathrm{C}$ ) to $6 \mu \mathrm{g}$ and $3 \mu \mathrm{g}$ (combination $\mathrm{B}$ and $\mathrm{A}$, respectively) reduced the transient $G U S$ expression indicating that in these combinations, DNA becomes the limiting factor and results in reduced transient $G U S$ expression. As the DNA and particle load was increased to 8 or $12 \mu \mathrm{g}$ DNA with $4 \mathrm{mg}$ particles, there was a reduction in transient GUS expression. The number of blue loci further decreased as the DNA and particle load was further increased to 10 or $15 \mu \mathrm{g}$ with $5 \mathrm{mg}$ particles. Increasing the number of DNA coated particles per shot did not enhance the transient GUS expression. This reduction in transient $G U S$ expression may be attributed to higher degree of damage to the tissues because of hitting higher number of DNA coated particles per unit area. From these experiments, it can be concluded that a particle load of $3 \mathrm{mg}(0.5 \mathrm{mg} / \mathrm{shot})$ is sufficient to produce high level of transient $G U S$ expression when used in conjunction with $9 \mu \mathrm{g}$ DNA (1:3 particle-DNA ratio).

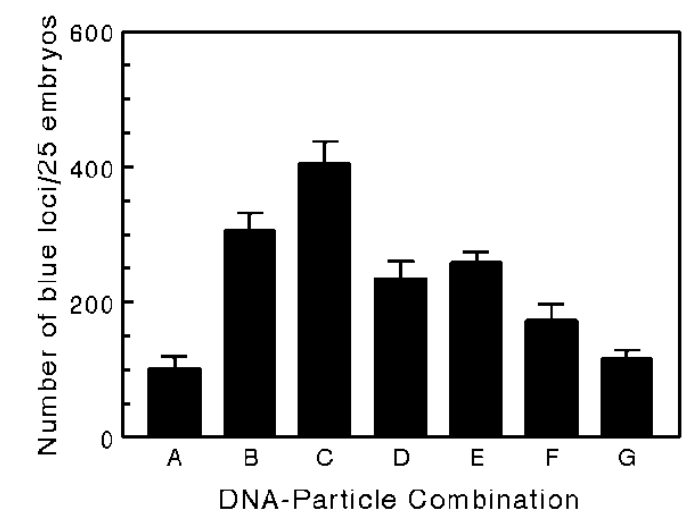

\begin{tabular}{cccc}
\hline Combination & $\begin{array}{c}\text { Particle load } \\
(\mathrm{mg})\end{array}$ & $\begin{array}{c}\text { DNA load } \\
(\mu \mathrm{g})\end{array}$ & Particle:DNA ratio \\
\hline A & 3 & 3 & $1: 1$ \\
B & 3 & 6 & $1: 2$ \\
C & 3 & 9 & $1: 3$ \\
D & 4 & 8 & $1: 2$ \\
E & 4 & 12 & $1: 3$ \\
F & 5 & 10 & $1: 2$ \\
G & 5 & 15 & $1: 3$ \\
\hline
\end{tabular}

Figure 4. Effect of different combinations (A-G) of DNA and particle loads on transient $G U S$ expression in mature embryos of B-370.

Effect of number of shots on transient GUS expression: After optimizing some of the important physical parameters described in the above two experiments, the effect of number of bombardments on transient GUS expression in mature embryos was studied. Using optimized bombardment conditions ( $3 \mathrm{mg}$ of $1.0 \mu \mathrm{m}$ gold particles; $9 \mu \mathrm{g}$ DNA), the embryos were bombarded at 6 and $9 \mathrm{~cm}$ with 1,100 psi helium pressure. At the target distance of $6 \mathrm{~cm}$, single shot resulted in higher number of blue loci $(476.5 \pm 44.5)$ compared to double shot $(321.0 \pm 60.8)$. A considerable increase in the number of blue loci was observed when embryos were 
bombarded twice at $9 \mathrm{~cm}$ target distance compared to single shot at the same distance. The reduced GUS expression at 6 $\mathrm{cm}$ with double shot may again be attributed to the tissue damage as a result of higher number of particles hitting per unit area. At $9 \mathrm{~cm}$, the particles dispersed uniformly to a wider area and thus causing less injury. From these results, it is clear that embryos can be bombarded twice at $9 \mathrm{~cm}$ to achieve higher transformation efficiencies. Therefore, all subsequent experiments were performed at $9 \mathrm{~cm}$ target distance with each plate bombarded twice.

Effect of osmotic treatment on transient GUS expression of bombarded mature embryos: Significant differences were observed between the control (CI medium having $2.0 \mathrm{mg} \mathrm{L}^{-1}$ $2,4-\mathrm{D}$ and $3 \%$ sucrose) and the osmotic treatments. Figure 5 shows the results of the osmotic treatment on transient GUS expression in mature embryos. Bombardment medium having $0.25 \mathrm{M}$ mannitol produced the highest number of blue loci $(900.0 \pm 47.5)$ followed by $0.4 \mathrm{M}$ mannitol $(832.0 \pm 39.0)$ while least $G U S$ expression $(313.0 \pm 20.2)$ was recorded in the control (3\% sucrose). Hence there was a 2.7 to 2.9 fold increase in transient GUS expression with media having 0.4 $\mathrm{M}$ and 0.25 M mannitol, respectively.

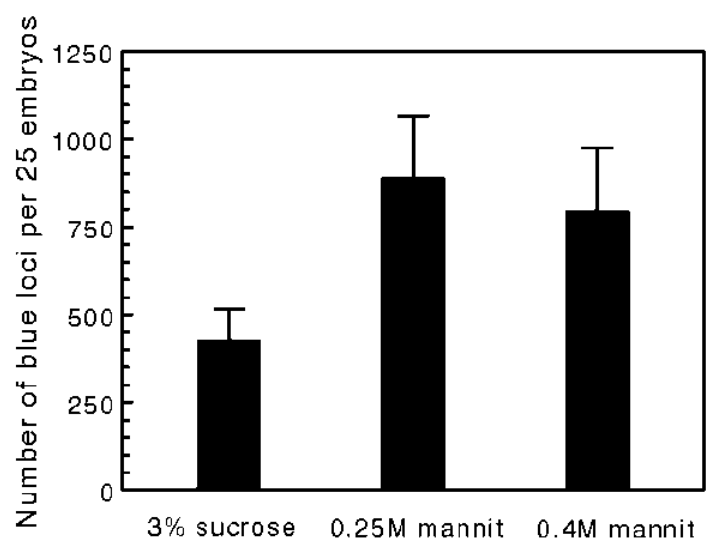

Figure 5. Effect of osmotic pre-treatment on transient GUS expression in mature embryos of B-370.
Selection and regeneration of putative transgenic plants: Embryos as well as primary embryogenic calli $(3-5 \mathrm{~mm}$ in size) were placed in triplicate on CI media containing 0,25 , 50,75 and $100 \mathrm{mg} \mathrm{L}^{-1}$ of hyg-B. Hyg-B at $25 \mathrm{mg} \mathrm{L}^{-1}$ did not completely inhibit the growth of calli and some sectors kept on growing even after 30 days of selection. At $50 \mathrm{mg} \mathrm{L}^{-1}$, after some initial growth the calli turned brown and no further growth was observed. At 75 and $100 \mathrm{mg} \mathrm{L}^{-1}$ hyg-B, callus growth was checked right from the beginning. It was therefore concluded that a concentration of $50 \mathrm{mg} \mathrm{L}^{-1}$ hyg-B is sufficient to kill non-transformed cells/calli. In the embryos placed on media having $25 \mathrm{mg} \mathrm{L}^{-1}$ hyg-B, some embryos started forming callus but at a very low frequency, whereas at 50, 75 and $100 \mathrm{mg} \mathrm{L}^{-1}$ hyg-B, no callus induction was observed and the embryos turned brown and necrotic. This indicated that at least $50 \mathrm{mg} \mathrm{L}^{-1}$ hyg-B was required to check the growth of non-transformed calli from embryos. After determining the optimum hyg-B concentration, the bombarded embryos were placed on selection medium (optimized CI medium containing $50 \mathrm{mg} \mathrm{L}^{-1}$ hyg-B). In eight different experiments, a total of 1,740 embryos were bombarded with plasmid pGH-1/pGH-II having GUS and hpt genes. Most of the bombarded embryos turned brown and necrotic after 7-8 days of culture on selection medium. Only few embryos showed transformed sectors from which hyg ${ }^{\mathrm{R}}$ callus originated as shown in Figure 2e. After two weeks, the $\operatorname{hyg}^{\mathrm{R}}$ calli were separated and placed on fresh selection medium. Results of these bombardment experiments are given in Table 2. Sixty-six calli survived the second round of selection. Some of these calli, stained for GUS activity, showed intense GUS staining as shown in Figure $2 \mathrm{f}$. These hyg $^{R}$ calli were first placed on optimized PR-1 medium (Table 1) for somatic embryo induction and then on the PR-2 medium (Table 1) for plant regeneration. Upon transfer to PR1, the calli developed somatic embryos within 10-12 days of culture. These somatic embryos germinated, upon transfer to PR-2 (Fig. 2g-i), to complete plants with simultaneous development of shoot and root. From the 66 hyg $^{R}$ calli, only 27 plants could be regenerated. These plants were then shifted

Table 2. Summary of bombardment, selection and regeneration from mature embryos of B-370.

\begin{tabular}{|c|c|c|c|c|c|c|c|c|c|c|}
\hline Cultivar & $\begin{array}{c}\text { Expt. } \\
\#\end{array}$ & $\begin{array}{c}\text { No. of } \\
\text { embryos } \\
\text { bombarded }\end{array}$ & $\begin{array}{c}\text { Total \# } \\
\text { of } \\
\text { plates }\end{array}$ & $\begin{array}{c}\text { Single } \\
\text { shot }\end{array}$ & $\begin{array}{c}\text { Double } \\
\text { shot }\end{array}$ & $\begin{array}{c}\text { Plasmid } \\
\text { Used }\end{array}$ & $\begin{array}{c}\text { No. of } \\
\text { Selected } \\
\text { Calli }\end{array}$ & $\begin{array}{c}\text { No. of } \\
\text { regenerated } \\
\text { plants }\end{array}$ & $\begin{array}{c}\text { No. of } \\
\text { Hyg/GUS } \\
\text { plants }\end{array}$ & $\begin{array}{c}\text { Transformation } \\
\text { efficiency } \\
(\%)\end{array}$ \\
\hline B-370 & 1 & 368 & 6 & 6 & - & pGH-I & 4 & 2 & 2 & 0.54 \\
\hline “ & 2 & 350 & 6 & 6 & - & pGH-II & 5 & 1 & 1 & 0.29 \\
\hline “، & 3 & 326 & 6 & 6 & - & pGH-I & 6 & 3 & 3 & 0.92 \\
\hline “" & 4 & 332 & 6 & 6 & - & pGH-II & 12 & 4 & 3 & 0.90 \\
\hline “، & 5 & 240 & 4 & 2 & 2 & pGH-I & 8 & 3 & 3 & 1.67 \\
\hline “" & 6 & 235 & 4 & 2 & 2 & pGH-II & 9 & 4 & 4 & 2.13 \\
\hline “" & 7 & 243 & 4 & 2 & 2 & pGH-I & 10 & 5 & 5 & 1.65 \\
\hline “" & 8 & 240 & 4 & 2 & 2 & pGH-II & 12 & 5 & 5 & 2.08 \\
\hline Total & & 1740 & & & & & 66 & 27 & 26 & 1.41 \\
\hline
\end{tabular}


to root proliferation (RP) medium (Table 1) for vigorous root development. The plants were removed from the RP medium and their roots were washed in running tap water, briefly dipped in $0.2 \% \mathrm{w} / \mathrm{v}$ Dithane $\AA$ aqueous solution and planted in sterilized sand. Of the twenty-seven plants shifted to pots, 26 plants survived and were successfully transferred to soil in the pots. These established plants were transferred to glasshouse for further growth and analysis.

Molecular analysis of putative transgenic plants: Genomic DNA isolated from all the 26 putative transgenic plants was subjected to PCR analysis. Figure 6 shows PCR analysis of 12 different putative transgenic plants with $G U S$ primers which amplified a correct sized (1,201 bp) fragment from the internal region of GUS gene. No amplification was obtained in non-transformed control and water control (no DNA control). This indicated that all these plants were positive for GUS gene. In another reaction, DNA from 14 putative plants transformed with pGH-1 were subjected to PCR analysis using hpt-F and CaMV35-R primers (Fig.7) which amplified $\sim 900$ bp fragment (between 3' region of the 35S promoter and 5' region of the hpt gene). Thirteen plants showed amplification of a specific sized fragment while one plant (Fig. 7; lane 12) did not show any amplification. This plant was, therefore, adjudged as negative for the transgene. However, to confirm these results, histological GUS assay was also performed on the leaves. Leaves from all the plants showed GUS expression except those which were found to be negative in PCR. The transgenic Basmati rice plants showed normal phenotype and were fertile. An optimized system for gene delivery to rice has therefore been developed for recovery of transgenic plants within a short period of time using a simple procedure applicable to other rice cultivars. This study has paved the way to transform other agronomically important genes for rice improvement.

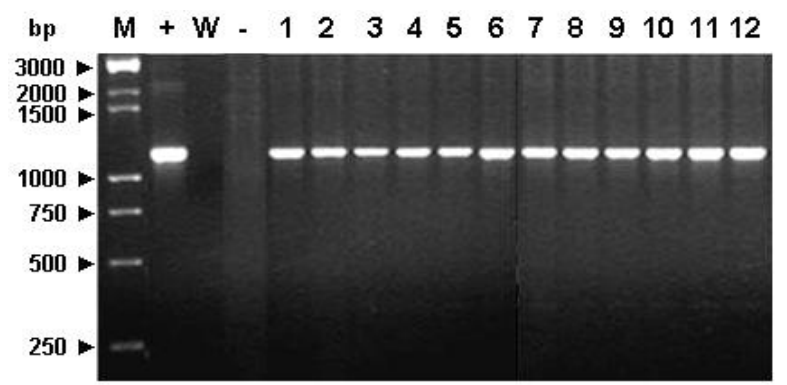

Figure 6.PCR analysis of putative transgenic B-370 lines transformed with pGH-I/pGH-II with $G U S$ specific primers. Lane $\mathrm{M}=1 \mathrm{kbp}$ DNA ladder (Fermentas cat \# SM0311); Lane + , positive control (pGH-1); Lane W, water control; Lane -, negative control (DNA from a non-transformed control plant); Lanes 1-12, different putative transgenic B-370 rice plants regenerated on selection media.

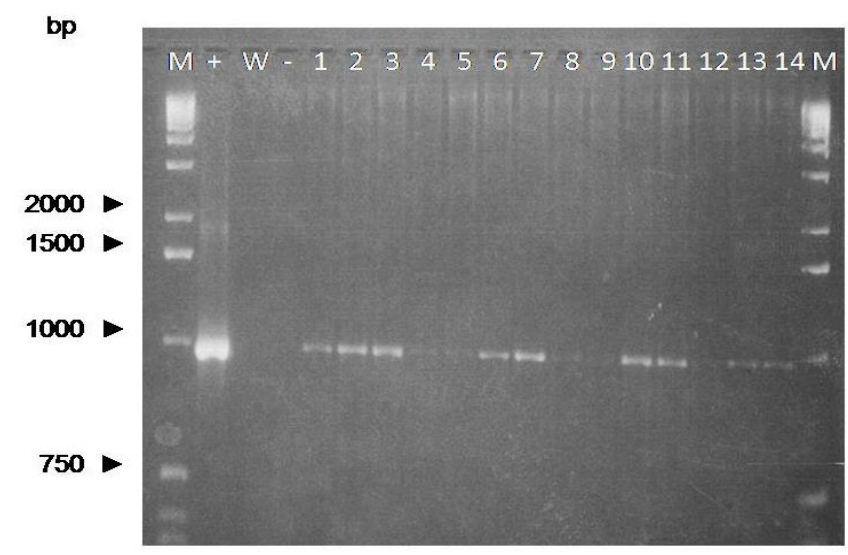

Figure 7.PCR analysis of putative transgenic B-370 lines transformed with pGH-1 with CaMV35S-F and hpt-R specific primers. Lane $\mathrm{M}=1 \mathrm{kbp}$ DNA ladder (Fermentas cat \# SM0311); Lane + , positive control (pGH-1); Lane W, water control; Lane -, negative control (DNA from a non-transformed control plant); Lanes 1-14, different putative transgenic Basmati-370 rice plants regenerated on selection media.

\section{DISCUSSION}

To define optimum conditions for high efficiency gene delivery through Biolistic approach, different parameters affecting bombardment efficiency were studied. Target tissue plays a vital role both in terms of transformation efficiency and transgenic plant recovery. In this study, both primary calli and mature embryos gave equally good results as far as transient GUS expression is concerned. A number of researchers have demonstrated the recovery of transgenic rice plants from embryogenic calli. Li et al. (1993) exhibited recovery of hundreds of transgenic plants from bombarded embryogenic calli of japonica and indica rice species. Chen et al. (1998) optimized the age of tissue for gene transfer and applied an improved selection procedure to recover transgenic Taipei 309 plants within 8 weeks at a frequency of $22.3 \pm 9.7$ per 100 calli. However, we observed that the selection efficiency of embryogenic calli is far less than the mature embryos. $\mathrm{Hyg}^{\mathrm{R}}$ calli originated mostly from the transformed sectors of the embryo scutellum giving a very early and clear indication of its transgenic nature. When these calli were separated from the mother explant and further sub-cultured on fresh selection medium, most of them exhibited a fast growth rate. On the other hand, it was difficult to judge transgenic nature of the hyg ${ }^{\mathrm{R}}$ calli that originated from the bombarded primary calli as siblings. Therefore, mature embryos offer a useful explant source for potential use in particlebombardment mediated gene delivery in rice.

Different physical factors were also optimized during the current study. It was observed that smaller particles $(1.0 \mu \mathrm{m})$ produced more number of blue loci on average compared to bigger particles $(1.6 \mu \mathrm{m})$ at 3,6 and $9 \mathrm{~cm}$ target distance. 
Lower transient GUS expression with $1.6 \mu \mathrm{m}$ particles may be the result of more damage to the tissue at these distances. However, relatively higher transient GUS activity was recorded at a target distance of $12 \mathrm{~cm}$. These results are in agreement with those reported by Zuraida et al. (2010). They showed that out of the various combinations of helium pressure and target distances used in their experiments on rice calli, maximum transient GUS activity was observed at 1,100 psi pressure and $9 \mathrm{~cm}$ target distance. High frequency of transient GUS expression at a helium pressure of 1,100 psi and a target distance of $9 \mathrm{~cm}$ was also found to be optimum in many other studies (Zhang et al., 1996; Chen et al., 1998; Jiang et al., 2000; Ramesh and Gupta, 2005; Matroodi et al., 2013).

The results show that higher DNA to particle ratio decreased the transient GUS expression in the bombarded embryos. This may be the result of agglomeration of gold particles at higher DNA concentration as seen during loading of the macrocarriers. Highest transient $G U S$ expression was recorded at 9 $\mu \mathrm{g}$ DNA with $3 \mathrm{mg}$ gold particles (3:1 DNA-particle ratio). These results are in agreement with the results reported by Ratnayaka and Oard (1995). They used different amounts of DNA loads and demonstrated that highest transient GUS activity was observed at $10 \mu \mathrm{g}$ DNA. They also showed that higher amounts of plasmid DNA (25 and $50 \mu \mathrm{g})$ dramatically reduced transient $G U S$ expression in rice suspension cells.

It was also observed that osmotic treatment significantly enhanced transient GUS expression compared to the controls. Treatment with $0.25 \mathrm{M}$ mannitol gave highest $G U S$ expression followed by $0.4 \mathrm{M}$ mannitol and yielded as much as 2.7 to 2.9 fold increase, respectively in transient $G U S$ expression over the control. Zhang et al. (1996) demonstrated 2.3 and 3.6 fold increase in transient GUS expression in IR64 and an advanced indica breeding line IR57311-95-2-3, respectively using medium containing 3\% mannitol, $3 \%$ sorbitol in addition to $3 \%$ sucrose for osmotic treatment. Similarly, Chen et al. (1998) showed significant enhancement of transient $G U S$ activity by placing rice calli on medium having $0.6 \mathrm{M}$ carbohydrate before and after the bombardment. An overall transformation efficiency of $1.5 \%$ was achieved in these experiments. These plants were phenotypically normal and fertile. Various studies on rice transformation have shown that indica rice exhibit low transformation efficiencies compared to highly responsive japonica rice cultivars. Sivamani et al. (1996) recovered 10-20 plants per 500 bombarded embryogenic calli with an overall transformation efficiency of $2-4 \%$ while Chen et al. (1998) obtained an efficiency upto $22 \%$ with Taipei 309 embryogenic calli. Cho et al. (2004); however, reported a higher particlebombardment mediated transformation efficiency $(6.5 \%)$ using highly regenerative green tissue of Taipei 309.

Conclusions: A simple, reproducible and efficient protocol for rice transformation through particle bombardment has been developed. Ultimately, this study will pave the way for genetic improvement of Basmati rice varieties especially for those characters which are otherwise difficult to achieve through conventional breeding methods.

Acknowledgements: The work presented in this manuscript is part of PhD studies of ZM. Authors thankfully acknowledge help of Mr. Yunus Malik for looking after the transgenic plants in containment glass house.

\section{REFERENCES}

Altpeter, F., N. Baisakh, R. Beachy, R.Bock, T. Capell, P. Christou, H. Daniell, K. Datta, S. Datta, P.J. Dix, C. Fauquet, N. Huang, A. Kohli, H. Mooibroek, L. Nicholson, T.T. Nguyen, G. Nugent, K. Raemakers, A. Romano, D.A. Somers, E. Stoger, N. Taylor and R. Visser. 2005. Particle bombardment and the genetic enhancement of crops: myths and realities. Mol. Breed. 15:305-327.

Asad, S., Z. Mukhtar, F. Nazir, J.A. Hashmi, S. Mansoor, Y. Zafar and M. Arshad. 2008. Silicon carbide whiskermediated embryogenic callus transformation of cotton (Gossypium hirsutum L.) and regeneration of salt tolerant plants. Mol. Biotechnol. 40:161-169.

Chen, L., S. Zhang, R.N. Beachy and C.M. Fauquet. 1998. A protocol for consistent, large scale production of fertile transgenic rice plants. Plant Cell Rep. 18: 25-31.

Cho, M. -J., H. Yano, D. Okamoto, H.-K. Kim, H.-R. Jung, K. Newcomb, V.K. Le, H.S. Yoo, R. Langham, B.B. Buchanan and P.G. Lemaux. 2004. Stable transformation of rice (Oryza sativa L.) via microprojectile bombardment of highly regenerative, green tissues derived from mature seed. Plant Cell Rep. 22:483-489.

Christou, P., T.L. Ford and M. Kofron. 1992. Rice genetic engineering: a review. Trends Biotechnol. 10:239-246.

Crossway, A., J.V. Oakes, J.M. Irvine, B. Ward, V.C. Knauf and C.K. Shewmaker. 1986. Integration of foreign DNA following microinjection of tobacco mesophyll protoplasts. Mol. Gen. Genet. 202:179-185.

Datta, S.K., A. Peterhans, K. Datta and I. Potrykus. 1990. Genetically engineered fertile Indica-rice plants recovered from protoplasts. Nat. Biotechnol. 8:736-740.

Finer, J., P. Vain, M. Jones and M. McMullen. 1992. Development of a particle inflow gun for DNA delivery to plant cells. Plant Cell Rep. 11:323-328.

Frame, B.R., P.R. Drayton, S.V. Bagnall, C.J. Lewnau, W.P. Bullock, H.M. Wilson, J.M. Dunwell, J.A. Thompson and K. Wang. 1994. Production of fertile transgenic maize plants by silicon-carbide whisker-mediated transformation. Plant J. 6:941-948.

Fromm, M.E., L.P. Taylor and V. Walbot. 1986. Stable transformation of maize after gene-transfer by electroporation. Nature 319:791-793. 
Ghareyazie, B., F. Alinia, C.A. Mentguito, L.G. Rubia, J.M. DePalma, E.A. Liwanag, M.B. Cohen, G.S. Khush and J. Benett. 1997. Enhanced resistance to two stem borers in an aromatic rice containing a synthetic cry1A(b) gene. Mol. Breed. 3:401-414.

Iqbal, M.J., N. Aziz, N.A. Saeed, Y. Zafar and K.A. Malik. 1997. Genetic diversity evaluation of some elite cotton varieties by RAPD analysis. Theor. Appl. Genet. 94:139144.

James, C. 2003. Preview: Global status of commercialized transgenic crops: 2003. ISAAA Briefs No. 30. ISAAA, Ithaca, NY.

Jefferson, R.A. 1987. Assaying chimeric genes in plants: the GUS fusion system. Plant Mol. Biol. Rep. 5:387-405.

Jiang, J., S.D. Linscombe, J. Wang and J.H. Oard. 2000. Highly efficient transformation of Oryza sativa rice lines from mature seed-derived calli and segregation of glufosinate resistance under field conditions. Crop Sci. 40:1729-1741.

Klein, T.M., E.D. Wolf, R. Wu and J.C. Sanford. 1987. High velocity microprojectiles for delivering nucleic acids into living cells. Nature 327: 70-73.

Kosugi, S., Y. Ohashi, K. Nakajima and Y. Arai. 1990. An improved assay for ß-glucuronidase in transformed cells: Methanol almost completely suppresses a putative endogenous ß-glucuronidase activity. Plant Sci. 70:133140.

Li, L., R. Qu, A. De Kochko, C. Fauquet and R.N. Beachy. 1993. An improved rice transformation system using the biolistic method. Plant Cell Rep. 12:250-255.

Matroodi, S., M. Motallebi, M. Zamani, A. Mousavi and D.Davoodi. 2013. Nco310 sugarcane transformation using Uida reporter gene. Int. J. Soil Plant Environ. Sci. $1: 1-9$.

Negrutiu, I., R.D. Shillito, I. Potrykus, G. Biasini and F. Sala. 1987. Hybrid genes in the analysis of transformation conditions. I. Setting up a simple method for direct gene transfer in plant protoplasts. Plant Mol. Biol. 8:363-373.

Ramesh, M. and A.K. Gupta. 2005. Transient expression of B-glucuronidase gene in indica and japonica rice (Oryza sativa L.) callus cultures after different stages of cobombardment. Afr. J.Biotechnol. 4: 596-600.

Ratnayaka, I.J.S. and J.H. Oard. 1995. A rapid method to monitor DNA precipitation onto micro-carriers before particle bombardment. Plant Cell Rep. 14:794-798.

Shillito, R.D., M.W. Saul, J. Paszkowski, M. Muller and I. Potrykus. 1985. High efficiency direct gene transfer to plants. Nat. Biotechnol. 3:1099-1103.

Sivamani, E., P. Shen, N. Opalka, R.N. Beachy and C.M. Fauquet. 1996. Selection of large quantities of embryogenic calli from indica rice seeds for production of fertile transgenic plants using the biolistic method. Plant Cell Rep. 15:322-327.

Zhang, S., L. Chen, R. Qu, P. Marmey, R. Beachy and C. Fauquet. 1996. Regeneration of fertile transgenic indica (group 1) rice plants following microprojectile transformation of embryogenic suspension culture cells. Plant Cell Rep. 15:465-469.

Zuraida, A.R., K. Rahiniza, M.R. Nurul-Hafiza, R. Suri, Z. Zamri and S. Sreeramanan. 2010. Factors affecting delivery and transient expression of gusA gene in Malaysian indica rice MR 219 callus via biolistic gun system. Afr. J. Biotechnol. 9:8810-8818. 